Юрченко А. В., аспірантка кафедри політологї Київського національного університету імені Тараса Шевченка

\title{
ПОЛІТИКО-ПРАВОВІ ЧИННИКИ ФОРМУВАННЯ НАЦІОНАЛЬНОГО АГЕНТСТВА УКРАЇНИ $З$ ПИТАНЬ ВИЯВЛЕННЯ, РОЗШУКУ ТА УПРАВЛІННЯ АКТИВАМИ, ОДЕРЖАНИМИ ВІД КОРУПЦІЙНИХ ТА ІНШИХ ЗЛОЧИНІВ
}

\begin{abstract}
Анотація. У статті проаналізовано політико-правові передумови та засади створення та формування Національного агентства України з питань виявлення, розшуку та управління активами, одержаними від корупційних та інших злочинів (далі - АРМА), центрального органу виконавчої влади зі спеціальним статусом. Розглянуто зміст повноважень, функцій та завдання центрального органу, що забезпечує формування державної політики у сфері виявлення та розшуку активів та управління активами; формування та введення Єдиного державного реєстру активів, на які накладено арешт або які конфісковано у кримінальному провадженні; участь у забезпеченні представництва прав та інтересів України у закордонних юрисдикційних органах у справах, пов'язаних 3 поверненням в Україну активів, одержаних від корупційних та інших злочинів. Автором розглянуто вплив політичних чинників на незалежну діяльність Національного агентства України з питань виявлення, розшуку та управління активами, одержаними від корупційних та інших злочинів та закцентувано увагу на міжнародному досвіді у сфері виявлення, розшуку активів, обміну інформацією щодо неправомірно отриманих активів. Визначено роль і місце у системі антикорупційних органів України.
\end{abstract}

Ключові слова: Національне агентство України 3 питань виявлення, розшуку та управління активами, одержаними від корупційних та інших злочинів, корупція, інститут, управління активами, антикорупційні органи, APMA.

Постановка проблеми. Національне агентство України 3 питань виявлення, розшуку та управління активами, одержаними від корупційних та інших злочинів (Агентство з розшуку та менеджменту активів або АРМА) є центральним органом виконавчої влади зі спеціальним статусом, уповноваженим на формування та реалізацію державної політики у сфері виявлення та розшуку активів, які можуть бути арештовані у кримінальному провадженні, а також управління активами, які арештовані у кримінальному провадженні. АРМА входить до системи нових антикорупційних органів в Україні, на яке покладена важлива функція протидії корупції, шляхом виявлення, розшуку та управління активами, а також участю у забезпеченні представництва прав та інтересів України у закордонних юрисдикційних органах у справах, пов'язаних з поверненням в Україну активів, одержаних від корупційних та інших злочинів. Створення АРМА було одним із основних критеріїв виконання Україною Плану дій з лібералізації візового режиму з ЄС. За змістом, обсягом функцій і правовим статусом АРМА не має аналогів у системі органів державної влади в Україні.
Важливим аспектом для наукового дослідження залишаються політико-правові передумови створення, а також політико-правові засади інституціоналізації органу.

Аналіз останніх досліджень і публлікацій. Сьогодні єзначна кількість вітчизняних досліджень вчених-теоретиків, а також фахівців у сфері протидії корупції, варто зазначити О.В. Бауліна, Л.М. Лобойко, Є.Д. Скулиша, Є.В. Невмержицького, М. Ховронюка, В.М. Тертишника, О.М. Юрченко, А.В. Самодіна. Проте наразі відсутні комплексні дослідження, що стосуються передумов виникнення та особливостей функціонування АРМА. Ця стаття грунтується на положеннях міжнародних нормативних актів, чинному законодавстві України, звітних матеріалах міжнародних організацій, конференцій, матеріалах АРМА та аналітичних звітах громадських організацій.

Метою наукової статті $€$ аналіз політико-правових передумов формування та особливостей функціонування Національного агентства України 3 питань виявлення, розшуку та управління активами, одержаними від корупційних та інших злочинів.

Виклад основного матеріалу. Корупція в Україні стала однією з причин, що призвели до масових протестів в Україні наприкінці 2013 - на початку 2014 років. Під час Революції Гідності численні високопосадовці та політики залишали Україну, зберігаючи можливість розпоряджатися коштами в іноземних банках. Після відповідних звернень до Генеральної прокуратори України активи колишніх чиновників були арештовані в Австрії, Швейцарії та накладені санкції з боку Європейського Союзу. Організація Global Financial Integrity підрахувала, що 3 України нелегально виводилося в середньому \$11,676 млрд упродовж 2004-2013 років, а всього за цей час - близько $\$ 116,762$ млрд.

Створення Національного агентства 3 повернення активів стало одним з основних критеріїв виконання Плану дій з лібералізації візового режиму з ЄС.

У рамках Антикорупційної стратегії 2014-2017 pр. у березні 2015 року було створено міжвідомчу робочу групу з координації повернення в Україну коштів, одержаних злочинним шляхом колишніми високопосадовцями України, котру очолив заступник Генпрокурора Віталій Касько. До складу ввійшли також представники Міністерства юстиції, Генеральної прокуратури, представники громадянського суспільства. Окремий висновок напрацьованому законопроекту надало Міністерство юстиції США.

Член Комітету експертів Ради Європи 3 оцінки заходів боротьби з відмиванням грошей MONEYVAL Джон Рінггат зазначав про те, що тема створення окремого агентства, котре 
опікувалося 6 пошуком та менеджментом сумнівного майна, набуло надзвичайної важливості для європейських правоохоронців у останні десятиріччя. Ці роки показали, що боротьба 3 організованою злочинністю часто виявлялася неефективною, адже злочинці, виходячи із в' язниці, знову отримували доступ до багатств, набутих незаконним шляхом. У цих обставинах у країнах Європи почали активно з'являтися відомства, які 6 розшукували такі активи та опікувалися б збереженням їхньої цінності в разі, якщо вони будуть конфісковані [9].

Створення АРМА також передбачено низкою міжнародних договорів, стороною яких є Україна, зокрема: Конвенцією про відмивання, пошук, арешт та конфіскацію доходів, одержаних злочинним шляхом [4], Конвенцією Організації Об'єднаних Націй проти корупції [6], Кримінальною конвенцією про боротьбу з корупцією [7] і Конвенцією Ради Свропи про відмивання, пошук, арешт та конфіскацію доходів, одержаних злочинним шляхом, та про фінансування тероризму [2; 3]. Міжнародна група 3 протидії відмиванню брудних грошей (International Standards on Combating Money Laundering and the Financing of Terrorism \& Proliferation. The FATF Recommendations) надала на виконання 38 рекомендацій, згідно з якими державам-учасницям рекомендовано створити органи, які б могли оперативно реагувати на запити аналогічних іноземних органів щодо виявлення, заморожування, арешту та конфіскації майна, отриманого незаконним шляхом. А також «Великою вісімкою» (G8) у межах підгрупи з кримінально-правових питань 27 квітня 2005 року схвалено кращі практики щодо адміністрування арештованих активів (G8 Best Practices for the Administration of Seized Assets) $[4 ; 5 ; 9]$.

Так, за підтримки міжнародних партнерів, адвокаційних зусиль громадянського суспільства та політичної волі влади 10 листопада 2015 року Верховна Рада прийняла Закон України «Про Національне агентство України з питань виявлення, розшуку та управління активами, одержаними від корупційних та інших злочинів» №772-VIII, яким визначила статус, завдання, функції АРМА і обов'язки працівників та інші питання діяльності нового центрального органу виконавчої влади: «Національне агентство України з питань виявлення, розшуку та управління активами, одержаними від корупційних та інших злочинів (далі - Національне агентство), є центральним органом виконавчої влади зі спеціальним статусом, що забезпечує формування та реалізацію державної політики у сфері виявлення та розшуку активів, на які може бути накладено арешт у кримінальному провадженні, та/або з управління активами, на які накладено арешт або які конфісковано у кримінальному провадженні».

Отже, Агентство підзвітне Верховній Раді України, підконтрольне та відповідальне перед Кабінетом Міністрів України. Згідно з прийнятим Законом основними завданнями APMA є:

1) забезпечення формування та реалізації державної політики у сфері: виявлення та розшуку активів, на які може бути накладено арешт у кримінальному провадженні; управління активами, на які накладено арешт або які конфісковано у кримінальному провадженні; управління активами, на які накладено арешт або які підлягають стягненню в дохід держави в позовному провадженні у справах про визнання необгрунтованими активів та їх витребування;

2) здійснення міжнародного співробітництва у сфері виявлення, розшуку та управління активами;
3) участь у забезпеченні представництва прав та інтересів України у закордонних юрисдикційних органах у справах, пов'язаних 3 поверненням в Україну активів, одержаних від корупційних та інших злочинів.

Задля забезпечення формування та реалізації державної політики в сфері виявлення, розшуку та управління активами AРМА розробляє проекти нормативно-правових актів, підзаконних актів, нормативно-правових актів, укладає міжвідомі міжнароді угоди про співробітництво 3 органами іноземних держав, до компетенції яких належать питання щодо виявлення, розшуку та управління активами, одержаними від корупційних та інших злочинів; надає роз'яснення, методичні та консультаційні допомоги слідчим, детективам, прокурорам та суддям з питань, пов'язаних з виявленням, розшуком, проведенням оцінки та управлінням активами; формує та веде Єдиний державний реєстр активів, на які накладено арешт у кримінальному провадженні, який повинен містити дані про активи, на які накладено арешт у кримінальному провадженні, судове рішення про арешт та/або скасування арешту, номер кримінального провадження у Єдиному реєстрі досудових розслідувань та іншу відповідну інформацію [1;2].

Г. Буяджи, Державний секретар Міністерства юстиції, зазначає, що подібні установи до Національного агентства існують у всіх 28 країнах - членах Європейського Союзу та більш ніж у 100 юрисдикціях по всьому світу. Основною передумовою створення таких установ у ЄС було Рішення Ради Європейського Союзу (2007/845/JНА від 06.12.2007) [2], згідно з яким держави - учасниці ЄС повинні заснувати офіси 3 питань розшуку та повернення активів, на які може бути накладено арешт у кримінальному провадженні (або надати аналогічні повноваження наявним органам). Другим ключовим актом права ЄС у відповідній сфері є Директива ЄС № 2014/42/EU від 03.04.2014 [3], яка передбачає необхідність вжиття заходів з ефективного розпорядження активами, на які накладено арешт, а також створення спеціальних інституцій, відповідальних за управління такими активами з метою їх збереження або збереження їх вартості. У Директиві зазначається, що 3 метою ефективного управління є можливість здійснення реалізації активів [2, с. 144].

Антон Янчук, голова АРМА, наголошував, що функції AРМА є зрозумілими для більшості країн світу, проте абсолютно новими в системі органів державної влади України, не кажучи вже про пересічних громадян. Хоча для більшості країн Європейського союзу наявність агенцій, тотожних АРМА - це давно уставлена практика. Таким чином, одна з функцій АРМАуправління арештованим майном - $є$ імплементацією відповідних практик $Є С$ з управління арештованим майном. Ця функція $€$ не просто черговою регуляторною діяльністю держави, а створює принципово новий механізм державно-приватного партнерства, аналогій якому в Україні не було» [13].

Отже, період інституційного оформлення АРМА характеризується прийняттям ряду законодавчих змін, покликаних забезпечити ефективну діяльність органу, політичних рішень, нормативно-правових актів тощо.

Необхідно також зауважити, що «Головою Національного агентства може бути громадянин України, який має вищу юридичну освіту, стаж роботи у галузі права не менше п'яти років, досвід роботи на керівних посадах в органах влади, органах місцевого самоврядування, юридичних особах в Україні або 
за кордоном чи у міжнародних організаціях не менше трьох років, володіє державною мовою та здатний за своїми діловими та моральними якостями, освітнім і професійним рівнем, станом здоров'я виконувати відповідні службові обов' язки [1]. Голова Національного агентства призначається на посаду Кабінетом Міністрів України строком на п'ять років за результатами конкурсу. Одна і та сама особа не може обіймати цю посаду два строки підряд». Відбір кандидата на посаду голови здійснює конкурсна комісія, до складу якої входять три особи, визначені Верховною Радою України; одна особа, визначена Генеральним прокурором; одна особа, визначена директором Національного антикорупційного бюро України; одна особа, визначена Міністром юстиції України; одна особа, визначена головою центрального органу виконавчої влади, що реалізує державну політику у сфері запобігання та протидії легалізації (відмиванню) доходів, одержаних злочинним шляхом, фінансуванню тероризму та фінансуванню розповсюдження зброї масового знищення; одна особа, визначена Міністром фінансів України.

Формування загального кадрового потенціалу органу здійснюється на конкурсній основі.

Необхідно зазначити, що невіддільним складником незалежної зовнішньої оцінки діяльності Національного агентства $€$ щорічний зовнішній аудит діяльності Національного агентства, який проводиться винятково міжнародною або національною аудиторською компанією [1]. Крім цього, діє механізм громадського контролю за діяльністю Національного агентства через Громадську раду при Національному агентстві. Конкурс із формування персонального складу Громадської ради при Національному агентстві здійснюється шляхом відкритого рейтингового інтернет-голосування громадян, які проживають на теритоpiї України. Представники громадських організацій, що входять до складу ГР або до складу конкурсних комісій на заміщення вакантних посад державних службовців у Національному агентстві, заслуховують на інформацію про діяльність, виконання планів і завдань Національного агентства, здійснють контроль за витрачанням коштів Державного бюджету України, надають висновки за результатами експертизи проектів нормативно-правових актів Національного агентства. Ради громадського контролю є діявими механізмами контролю громадськості у майже всіх новостворених антикорупційних органах України.

В управлінні АРМА, станом на вересень 2019 року, знаходиться понад 1540 активів, на які накладено арешт у кримінальних провадженнях, з яких: 890 об'єктів нерухомого майна, 83 об' єкти (групи об'єктів) рухомого майна; 507 транспортних засобів (усе інше майнові права та грошові кошти). Станом на кінець 2019 року до АРМА для зберігання згідно з ухвалами слідчих суддів надійшло грошових коштів у сумі: 9835033 грн.; 215200 доларів США; 1265250 Євро. Загальна вартість активів, які фактично перебувають в управлінні АРМА, складає понад 3,5 млрд гривень [14].

Важливу роль у інституалізації АРМА відіграли та продовжують відігравати міжнародні партнери та їх підтримка. Так, європейські партнери неодноразово долучалися до організації та проведення спеціалізованого навчання співробітників AРMA, сприяли розвитку через підтримку у питаннях обміну та доступу до інформації, а також підтримували широке залучення представників медіа і громадянського суспільства до практичного упровадження антикорупційної реформи й моніторингу їі впровадження.
Посол Данії в Україні Рубен Мадсен, виступаючи на відкритті Українського форуму з управління арештованими активами «Форма», зазначив, що Данія продовжує підтримувати Україну на шляху реформ, зокрема у сфері боротьби з корупцією. Важливим напрямом він назвав підвищення спроможності вже утворених антикорупційних інституцій, зокрема АРМА. Посол підкреслив, що успішна робота 3 арештованими активами багато в чому залежить від результатів роботи судової системи, але і значення АРМА тут не менш важливе. «Адже в Україні все ще є структури, які присвоюють кошти, що мають бути використані на благо країни, на створення нових робочих місць і підвищення добробуту громадян. Саме АРМА повертає ці ресурси».

Раніше керівник Програм співробітництва Представництва Європейського Союзу в Україні Штефан Шльойнінг зазначив, що допомога в боротьбі з корупцією - це один $з$ основних напрямів підтримки України з боку ЄС з часів Революції Гідності. Він зазначив, що АРМА, хоч іє новою інституцією, та вже довела свою ефективність, зокрема, завдяки обміну досвідом і успішній співпраці з аналогічними структурами у країнах членах ЄС. Штефан Шльойнінг наголосив, що ЄС і надалі підтримуватиме цей напрям, оскільки робота антикорупційних структур дуже важлива для економічного зростання і повернення довіри громадян України до таких органів.

Висновки. Отже, для створення АРМА існували внутрішні та зовнішні передумови:

потреба у вдосконаленні механізмів виявлення та розшуку активів, які було незаконно виведено за межі України внаслідок вчинення корупційних та інших злочинів, а також необхідність запровадження прозорих та ефективних механізмів управління арештованими активами; зобов'язання України в рамках виконання Плану дій щодо лібералізації ЄС візового режиму для України, обов'язкові для України рекомендації Організації економічного співробітництва та розвитку (OECP) та інші міжнародні зобов'язання України. АРМА за змістом, обсягом функцій і правовим статусом не має аналогів у системі органів державної влади в Україні. Станом на сьогодні АРМА співпрацює з установами, що мають аналогічні повноваження щодо розшуку та менеджменту активів і знаходяться у 28 країнах - членах Європейського союзу та більш ніж у 100 юрисдикціях по всьому світу [14]. Агентство авторизовано та виступає партнером таких універсальних міжнародних утворень, як:

- Камденська міжвідомча мережа 3 повернення активів (CARIN);

- Глобальна мережа контактних пунктів Міжнародної організації кримінальної поліції (Interpol);

- Ініціатива 3 повернення вкрадених активів (StAR);

- Європейський поліцейський офic (Europol);

- п'ять міжвідомчих мереж 3 повернення активів Азійсько-Тихоокеанського регіону, Південно-Африканського регіону, Східно-Африканського регіону, Західно-Африканського регіону та Карибського регіону;

- Платформа установ 3 повернення активів держав - членів Європейського Союзу;

- Міжвідомча мережа 3 управління активами Балканського регіону (BAMIN);

- Конференція держав - учасниць Конвенції ООН проти корупції (UNCAC); 
- Стамбульський план дій по боротьбі 3 корупцією Антикорупційної мережі для Східної Європи та Центральної Азії Організації економічного співробітництва та розвитку (OECP) [14].

Співробітництво 3 міжнародними, міжурядовими організаціями, мережами, діяльність яких спрямована на забезпечення міжнародного співробітництва у сфері виявлення, розшуку та управління активами в частині обміну досвідом та інформацією з питань, пов'язаних з виявленням, розшуком та управлінням активами, є одним 3 приорітетних напрямів діяльності Національного агентства. Інституційне оформлення органу $€$ незавершеним на цей час, проте АРМА повною мірою виконує реалізацію покладених законодавством функцій.

\section{Лimepamypa:}

1. Про Національне агентство України з питань виявлення, розшуку та управління активами, одержаними від корупційних та інших злочинів : Закон України від 10.11.2015 No772-VIII. URL: http://zakon3.rada.gov.ua/laws/show/772-19.

2. Буяджи Г. Історія формування та передумови виникнення національного агенства України з питань виявлення, розшуку та управління активами, одержаними від корупційних та інших злочинів / Підприємництво. Господарство і Право, № 3, 2018. С. 143-147.

3. Council Decision 2007/845/JHA of 6 December 2007 concerning cooperation be- tween Asset Recovery Offices of the Member States in the field of tracing and identification of proceeds from, or other property related to, crime. URL: http://eur-lex.europa.eu/legal-content/ EN/TX- T/?uri=CELEX\%3A32007D0845.

4. Directive 2014/42/EU of the European Parliament and of the Council of 3 April 2014 on the freezing and confiscation of instrumentalities and proceeds of crime in the European Union. URL: http:// eur-lex.europa.eu/legal-content/EN/TX- T/?uri=CELEX\%3A32014L0042.

5. Конвенція про відмивання, пошук, арешт та конфіскацію доходів, одержаних злочинним шляхом, від 08.11.1990. URL: http://zakon2. rada.gov.ua/ laws/show/995_029/conv.

6. Конвенція Організації Об'єднаних Націй проти корупції від 31.10.2003. URL: http://zakon2.rada.gov.ua/laws/show/995_c16/ conv.

7. Кримінальна конвенція про боротьбу з корупцією (ETS 173) від 27.01.1999. URL: http://zakon3.rada.gov.ua/laws/show/994_101/ conv.

8. Закон України «Про запобігання корупції», 2016. 76 с. (Кодекси та Закони України).

9. Кримінальний процесуальний кодекс України. Харків : Право, 2018. 364 c

10. Закон України «Про затвердження Державної програми щодо реалізації засад державної антикорупційної політики в Україні (Антикорупційної стратегії) на 2015-2017 роки». URL: http://zakon3.rada.gov.ua/laws/show/1699-18.

11. Спеціалізовані інституції з боротьби проти корупції: огляд моделей. Організація економічного співробітництва і розвитку: Мережа боротьби проти корупції для країн Східної Європи і Центральної Aзiï, 2007. 131 c. URL: http://www.oecd.org/ dataoecd/7/9/3997 2100.pdf.

12. Науково-практичний коментар Закону України «Про запобігання корупції. О.А. Банчук, О.О. Дудоров, В.В. Луцик, В.П. Попович, О.В. Сорока, М.І. Хавронюк; за заг. ред. М.І. Хавронюка. Київ, 2017.

13. Янчук А. Управління арештованим майном - новий механізм державно-приватного партнерства. URL: https://ukr.lb.ua/blog/anton yanchuk/383338_upravlinnya_areshtovanim_maynom-.html

14. Потьомкін А. Правда про APMA. URL: http://yur-gazeta.com/ publications/practice/inshe/pravda-pro-arma.html.

Yurchenko A. Political and Legal factors of formation of the National Agency of Ukraine for finding, tracing and management of assets derived from corruption and other crimes

Summary. The article conducts analysis of the political and legal basics and principles of formation of the National Agency of Ukraine for finding, tracing and management of assets derived from corruption and other crimes (abbr. Asset Recovery and Management Agency or ARMA), which is a special governmental body, authorized to formulate and implement state policy in the sphere of tracing, finding of assets that are subject to seizure and that are aimed to be seized, as well as management of seized assets in criminal proceedings. The author explores the responsibilities, functions and tasks of a central body that ensures the formulation of state policy in the area for finding and tracing of assets; developing and keeping of the Unified State Register of Assets Seized in Criminal Proceedings, which shall contain, for instance, information on assets, which have been seized in criminal proceedings, court decision on seizure and/or cancellation of seizure, number of criminal proceedings in the Unified Register of Pre-Trial Investigations and other relevant information; taking part in representation of the State of Ukraine in foreign jurisdictional bodies in cases related to return of assets derived from corruption and other crimes. In addition, the article pays attention to the impact of political factors on the independent activities of the National Agency of Ukraine for finding, tracing and management of assets derived from corruption and other crimes. The article is devoted to the international cooperation with relevant authorities of foreign states, international organizations dealing in this sphere by taking measures on tracing and finding of assets as well as requesting them on asset finding and tracing activities; The content of the powers, functions and tasks of the ARMA is considered, and its role and place in the system of anticorruption bodies of Ukraine are determined.

Key words: National Agency of Ukraine for finding, tracing and management of assets derived from corruption and other crimes; corruption; institution; management of assets; anti-corruption agency; ARMA. 